\title{
The economic assessment on the utilizing of bottom ash as the bio coal fuel
}

\author{
Dyah Marganingrum ${ }^{1 *}$, Chandra Irawan ${ }^{2}$, Anggoro Tri Mursito ${ }^{1}$, Lenny Marilyn Estiaty ${ }^{1}$, Lina \\ Nur Listyowati ${ }^{1}$, Danang Noor Arifin ${ }^{1}$, \& Hidawati ${ }^{1}$ \\ ${ }^{1}$ Research Centre for Geotechnology-LIPI \\ ${ }^{2}$ Research Group of Media Energi Nusantara, chandra20112011@gmail.com \\ *dmarganingrum@yahoo.com
}

\begin{abstract}
Coal ash was included in Hazardous and Toxic Waste (LB3). It required manage seriously so it was not warm to environment and human's health. LB3 management becomes an obligation for the industry which producing itself. This condition becomes a burden to industry itself due to the waste utilization project often regarded as the high-cost investment projects or less profitable. This study aims to conduct an economic assessment of pilotscale projects in bottom ash utilizing to support the clean industry strategy. The study mixed coal bottom ash with biomass from municipalities solid waste (MSW), called bio-coal fuel (BCF). These raw materials were combined by a composition of $60 \%: 40 \%$ weight (bottom ash: biomass) to be briquette by adding amylum as a binder. This study used the benefit-cost analysis approach to assess economic feasibility. Tree indicators used in this study were net benefit-cost ratio, payback period, and return on investment. These indicators provided the company policy to continue or stop this project. The finding study showed air emission test under emission standard and burning test did not disturb to boiler perform. Financial calculation showed that the company got a payback period and net benefit from ninth year. The company also achieved a net B/C ratio was more than one, and ROI was 1.09 times in ninth year. The other beneficiaries acquired by the company was included external costs, such as risks from commitment failure by third parties in coal waste management, costs rising risk of purchasing coal, and given a positive value for providing employment.
\end{abstract}

Keywords: benefit, cost, pilot project, waste

JEL Classification: A19, Y40, Y80

\section{Abstrak}

Abu dasar batu bara termasuk dalam Limbah Bahan Berbahaya dan Beracun (LB3) yang memerlukan penanganan serius agar tidak membahayakan lingkungan dan kesehatan manusia. Pengelolaan LB3 menjadi kewajiban bagi industri penghasil LB3 dan menjadi beban tersendiri industri tersebut sehingga proyek pemanfaatan LB3 sering kali dianggap sebagai proyek investasi mahal atau kurang menguntungkan. Penelitian ini bertujuan untuk melakukan kajian ekonomi pada proyek skala pilot dalam pemanfaatan bottom ash untuk mendukung strategi industri bersih. Abu dasar batu bara dicampur dengan biomassa dari limbah padat perkotaan (MSW), yang kemudian disebut bahan bakar bio-batu bara. Bahan baku teresebut dicampur dengan komposisi 60\%:40\% berat (abu dasar:biomassa) menjadi briket dengan menambahkan amylum sebagai bahan pengikat. Studi ini menggunakan pendekatan analisis biaya-manfaat untuk menilai kelayakan ekonomi. Tiga indikator yang digunakan dalam penelitian ini adalah net benefit-cost ratio, payback period, dan return on investment. Indikator-indikator ini memberikan dasar kebijakan bagi perusahaan untuk melanjutkan atau menghentikan proyek tersebut. Hasil studi menunjukkan bahwa emisi udara di bawah baku mutu dan uji pembakaran tidak mengganggu kinerja boiler semula. Perhitungan finansial menunjukkan bahwa perusahaan mendapatkan payback period dan keuntungan bersih pada tahun kesembilan. Perusahaan juga mencapai rasio B/C bersih lebih dari satu, dan ROI sebesar 1,09 kali pada tahun kesembilan. Manfaat lain yang diperoleh perusahaan termasuk biaya eksternal, seperti risiko kegagalan komitmen pihak ketiga dalam pengelolaan limbah batu bara, risiko biaya pembelian batu bara, dan juga nilai positif dalam penyediaan lapangan kerja.

Kata kunci: biaya, keuntungan, limbah, proyek pilot

Klasifikasi JEL: A19, Y40, Y80

(C) 2021 The Author(s). Published by LIPI Press. This is an open access article under the CC BY-NC-SA

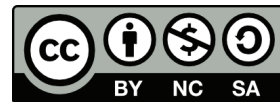
license (https://creativecommons.org/licenses/by-nc-sa/4.0). 


\section{INTRODUCTION}

Almost 90\% of Indonesia's energy needs are supplied from fossil fuels, especially oil and coal (Anindhita et al., 2015; Imaduddin et al., 2014; Yudiartono et al., 2018). The release of Government Regulation Number 79 of 2014 about National Energy Policy, Indonesia will still depend on energy sources from coal to reach $30 \%$ minimum in 2030 and $25 \%$ minimum in 2050 . The fundamental policy is that coal has sufficient abundant reserves with lower usage levels (Reserve and Production ratio of coal is 500 years) while oil is only 16 years, and its price increases continually (Anindhita et al., 2015; Mardansyah, 2008; Yusuf, 2012). The data of the World Energy in the Statistical Review showed that the oil reserve and coal were 0.3 and 39,891 thousand million tons respectively in 2019 year. Whereas the production of oil and coal in 2019 year were 38.2 and 610 million tons respectively. Based on the data, the ratio of reserve and production of coal is 7 thousand times greater than oil. So coal is still the dominant primary energy source in Indonesia, especially to meet the industrial energy demand.

There was increasing the coal using in many industries. This is caused by the coal price is lower than the price of oil. Almost all textile industries in Java Island have switched to use the coal fuel (Haryadi \& Suciyanti, 2018; Sulistyowati, 2013). The increased use of coal has caused the problem of FABA (fly ash and bottom ash) disposal to be more serious. The coal combustion will produce $\pm 20 \%$ of the total coal ash consisting of $20 \%$ fly ash and $80 \%$ bottom ash (Karo-karo \& Sembiring, 2008). The electric steam power plant (PLTU) owned by PT. Semen Tonasa with $2 \times 25 \mathrm{MW}$ and $2 \times 35 \mathrm{MW}$ capacity produce 41.62 tons of bottom ash every day (Yunita, 2017). We can imagine how many tons of FABA if the coal using increase year by year. Therefore, we need the simple technological breakthroughs that can be done massively by all industries which using coal as a fuel.

The law number 32 of 2009 article 59, paragraph 1 states that FABA is categorized as hazardous and toxic waste (Limbah Bahan Berbahaya dan Beracun or LB3). Therefore, the FABA needs to be managed carefully because it harms to human health and the environment.
The law number 32 of 2009 and the Government Regulations number 101 of 2014 about the Environmental Protection and Management also explained the hazardous and toxic waste management. These regulations state that everyone who produces LB3 is obliged to manage the LB3 that they produced. In other words, the LB3 management is the LB3 producer's responsibility. It's management responsibility can be transferred to the third party who has a business license of LB3 management if the producer of LB3 cannot manage by themselves. Therefore, this study has the primary concern of coal ash utilization regarding to minimize their storage and disposal. The volume increase of coal ash continuously will decrease the ash storage facilities (in cases of limited area for landfill expansion) and increase in handling, transporting, and costs (James et al., 2012). The study of bottom ash utilizing can be an alternative to overcome this problem. The bottom ash can be used as a fuel material into briquettes form (Marganingrum et al., 2020) which be reused by company itself. The specific objectives of this study was to evaluate the economic feasibility of bottom ash utilizing project as the material of briquettes fuel.

\section{LITERATURE REVIEW}

The coal ash increasing needs further study to find the properly technologies for ash processing and utilizing. However, research on bottom ash utilizing has not been done as much as fly ash (James et al., 2012). The current FABA utilizing is to civil engineering applications generally such as road construction, dykes, building materials, geopolymer applications, and in cement production (Estiaty et al., 2013; Jayaranjan et al., 2014; Prasandha et al., 2015; Santoso \& Roy, 2003), while coal waste for energy sources or fuel is still very limited. This related to low heating value of coal waste due to the inadequate volatile matter content to burn again. Based on this, several previous studies do the mixing of bottom ash with biomass to increase the caloric value (Estiaty, et al., 2018; Slamet \& Gunawan, 2016; Triantoro et al., 2019).

The Government Regulation No. 101 of 2014 states that the LB3 producer, including ash coal combustion, can utilize their LB3. This 
LB3 can be reused, recycled, and recovered to convert other product that can be used as a substitute for raw materials, auxiliaries, and fuels for themselves under safe for human health and environment. Hold this regulation the study was conducted on the bottom ash utilizing as a fuel alternative (Marganingrum et al., 2020). That study was done in one of weaving and textile industry. This study was continued on a pilot scale to determine its economic feasibility. The question rising is would its benefits outweigh its costs? While waste disposal management activities were invisible in the short term, so often, it is undervalued. It was also defined as the external cost, including environmental and social costs (Jugović et al., 2018; Wang et al., 2015).

The textile industry in West Java is one of the sectors experiencing loss due to competitiveness and the rupiah's exchange rate (Kurniadi et al., 2017; Zultaqawa et al., 2019). In challenging economic conditions, many textile industries were burdened with the cost of coal waste disposal. One solution was utilizing waste become to be a valuable product for their purposes. It would reduce the cost of waste managing and providing a source of income for the company itself (Kamble et al., 2019). To avoid undesirable losses in waste using, an economic analysis is needed. This study aims to assess the financial feasibility for coal bottom ash or unburnt carbon utilizing in the briquette form to be substituted fuel in the textile industry. The assessment is applied to the pilot plant scale. The feasibility assessment could help this company in decision making to implement the pilot project or not.

Feasibility study can be done in many aspects such as market, technical, management, law and social, and then economic and financial. The financial aspects can be analyzed using the Cost Benefit Analysis (CBA) which is consists of Net Present Value (NPV), Net B/C Ratio, Internal Rate Return (IRR), and Payback Period (PP) (Pratiwi et al., 2020). This study also used the cost-benefit analysis (CBA) approach to assess financial feasibility on the pilot project of bottom ash and unburnt carbon utilizing. The $\mathrm{CBA}$ is to provide the information regarding the product applied by company owners. As like the other economic valuation methods, $\mathrm{CBA}$ is an economic tool used to compare the benefits against the costs of a given project or activity (Chadburn et al., 2013; Sososutiksno \& Gasperz, 2017), can be used to assess the economic risk of a project (de Ruig et al., 2020), or determine the feasibility of a project or activity (Johnson, 2014). CBA was widely applied in various fields such as environment (Babalola, 2020; Makul, 2020; Špačková \& Straub, 2015), energy (Sidhu et al., 2018), health (Barstow et al., 2019; Botfield et al., 2020), disaster (Wild et al., 2019), water resources adaptation (de Ruig et al., 2020) etc.

Financial feasibility using Net B/C Ratio, payback period, and return on investment has be done on Poultry Chicken Farm (Elpawati et al., 2018). In this case, net $B / C$ ratio was 0.15 . If the $\mathrm{B} / \mathrm{C}$ ratio is lower than one, the business is likely will experience a loss, so it is necessary to increase amount of production (Palupi et al., 2020). In the other case also found that the financial analysis results gave a Net B/C Ratio of 0 , an IRR of 9.77 percent, and a return on investment of 20.3 years, which means that the project investment is not feasible (Pratiwi et al., 2020). NPV changes, Net B/C Ratio, IRR, and PP can occur because of certain changes. Therefore, we also need to do the sensitivity analysis to see eligibility business plan when things change to cost and benefit (Pratiwi et al., 2020). The sensitivity analysis will provide an overview of the extent decisions will be strong enough against with change in parameter influence. Sensitivity analysis done by changing parameters value which are then viewed how it affects the acceptability of an investment.

\section{RESEARCH METHOD}

\section{Case Study Background}

This study was done at one of the textile industries located in Bandung District, West Java-Indonesia, on the pilot plant scale. The industry has been experiencing a financial burden since the 1997 monetary crisis. However, they continue to run their business by complying with environmental regulations in their ash coal management. Some study activities are being carried out in collaboration with the Indonesian Institute of Sciences (LIPI) to utilize industrial waste. The aim was none other than toward a clean industry in 
addition to reducing the corporate expenses cost. In this case, we were trying to utilize bottom ash and unburnt carbon as substitution fuel in their boiler machine. Although still limited, studies using coal bottom ash were conducted (Syafrudin et al., 2015), and bottom ash briquetting was done to reduce the unburnt carbon (James et al., 2012).

The bottom ash utilizing becomes to be briquette was done by adding biomass purchased from outside parties. The function of biomass adding was to increase the burning level of bottom ash. A finding study by Kamble et al. (2019) shown co-gasification of coal and biomass has been emerging as potential clean fuel technology to achieve high thermodynamic efficiency with relatively low $\mathrm{CO} 2$ emission. This study used coal waste, so that provides certainly lower emission. The composition of the product was $60 \%$ weight of bottom ash and $40 \%$ weight of biomass. This formulation was based on previous study as an optimum formulation of briquette (Marganingrum et al., 2020). The briquetting process was done by adding the amylum as a binder of $2.5 \%$ product briquetting weight. Amylum was used in this study because it was easily available in the market at an affordable price.

This study assumes that the company purchases biomass continually from outside parties at the price of $\mathrm{Rp} 750 / \mathrm{kg}$. The assumption was used in this study because the biomass that used in this study was still free for a trial. Whereas the biomass price from the outside party was Rp 750/kg. The biomass composition consisted of municipal solid waste (MSW) and Eichornia crassipes (Eceng Gondok), which had been fermented. MSW's utilization is nothing to worry about because the United States Environmental Protection Agency (US EPA) has declared MSW incineration as a cleaner source of energy (Azam et al., 2020). Moreover, this waste biomass will be burned in a boiler with a higher temperature. Thus, the mixture of bottom ash and waste biomass products will be one solution to overcome the significant barriers in biomass systems' high investment costs due to intense competition with fossil fuels (Malico et al., 2019).

This industry has three boiler machines, namely Omnical Boiler (fluidized bed), Bertrams Konus Oil Boiler (fluidized bed) and Actom John Thompson Boiler (chain grate). The average uses of coal in these boilers are 7 ton/day, 2.3 ton/ day, and 18 ton/day, respectively. The coal waste produced from all three boilers is as much 3 ton/ day. The disposal fee of coal waste is Rp $165 / \mathrm{kg}$. The waste of coal combustion contained $150 \mathrm{~kg} /$ day of bottom ash.

Reusing of bottom ash as substitution fuel was only used in Omnical Boiler. The amount of coal substitution by briquettes is approximately $10 \%$ of coal used. We did the boiler observation for one month continuously. We produced \pm $250 \mathrm{~kg} /$ day of briquette according to bottom ash availability and engine capacity for briquetting. We collected briquette production sample and raw material as well. The substitution processing was conducted for 8 hours from 08.00 am until 04.00 $\mathrm{pm}$ in Omnical Boiler (Figure 1).

\section{Method}

This study used the Cost-Benefit Analysis (CBA) approach for assessing of economic and financial feasibility of bottoms ash or unburnt carbon utilizing as substitution fuel in the textile industry. The CBA types were consisted of three types, namely ex-ante, in medias res, and ex-post. In this study, the kind of CBA that we applied was in media res due to the financial assessment was conducted during the life of a current project (Boardman et al., 2011; Brubakken, 2020).

The determinate of decision rule based on CBA was generally described in the following equation (Turner et al., 1994):

$$
\begin{aligned}
& \sum_{t}\left(B_{t}-C_{t}\right)(1+r)^{-t}>0 \\
& \sum_{t}\left(B_{t}-C_{t} \pm E_{t}\right)(1+r)^{-t}>0
\end{aligned}
$$

$B_{t}$ is the benefit in year $t, C_{t}$ is a cost in year $t, E_{t}$ is the environmental or social cost in year $t, r$ is the discount rate, and $t$ is time preference.

CBA is comparison total present value between the benefit flow and the current cost flow based on the opportunity cost of capital invested (Elpawati et al., 2018). Besides implemented Present Net Value (NPV), three indicators of feasibility investments were applied (Sososutiksno \& Gasperz, 2017), such as Net Benefit-Cost Ratio (Net B/C), Payback Period (PB) (Mandasari et al., 2016; Nurmalina \& Riesti, 2010; Pasaribu \& Sukandar, 2017), and Return of Investment (ROI) (Masters et al., 2017). 


\section{Net Present Value (NPV)}

Net Present Value (NPV) was the present value of the net profit gained from a project. NVP in this study was formulated as follows (Nurmalina \& Riesti, 2010; Setiawan et al., 2019):

$$
\begin{aligned}
& N P V=\sum_{t=1}^{n} \frac{B_{t}-C_{t}-K_{t}}{(1+r)^{t}} \\
& N P V=\sum_{t=1}^{n} \frac{B_{t}-C_{t}-K_{t}}{(1+r)^{t}}
\end{aligned}
$$

$B_{t}$ is benefit in the first year to $t$ year, $C_{t}$ is cost in the first year to $t$ year, $\mathrm{K}_{t}$ capital used in the investment period, $\mathrm{r}$ is discount rate, and $\mathrm{t}$ is time preference. The feasibility economic based on NPV is as follow:

- NPV >0 means a project already declared profitable and feasible implemented.

- $\mathrm{NPV}=0$ means the project is not profitable and is not loss or in the other words the project is able to return exactly equal social capital Opportunities Cost factor normal production.

- $\mathrm{NPV}<0$ means a project is not feasible implemented

\section{Net Benefit Cost Ratio (Net B/C)}

Net Benefit-Cost Ratio (Net B/C) is a numerical comparison between current values benefits divided by present value cost flow (Elpawati et al., 2018; Pratiwi et al., 2020). The number shows the magnitude of additional benefits on each an additional cost of one unit money. The project can be accepted and continued if $\mathrm{Net} \mathrm{B} / \mathrm{C}$ is one or more. Net $\mathrm{B} / \mathrm{C}$ was formulated as follows:

$$
\operatorname{Net} \frac{B}{C}=\frac{\sum_{n=1}^{t} \frac{\sigma_{t}}{(1+r)^{t}}}{\sum_{n=1}^{t} \frac{C_{t}}{(1+r)^{t}}} \operatorname{Net} \frac{B}{C}=\frac{\sum_{n=1}^{t} \frac{\sigma_{t}}{(1+r)^{t}}}{\sum_{n=1}^{t} \frac{C_{t}}{(1+r)^{t}}}
$$

$B_{t}$ is benefit in the first year to $t$ year, $C_{t}$ is cost in the first year to $t$ year, $r$ is discount rate, and $t$ is time preference.

\section{Payback Period (PB)}

The payback period $(\mathrm{PB})$ is the ratio between investment expenditures with the benefits in a certain time (Isamu et al., 2018) or the period of return of investment incurred through the net benefit obtained. This PB calculation already calculates the time value of money because the net benefit amount is obtained using the interest rate factor (Nurmalina \& Riesti, 2010). Sometime to calculate the payback period also could ignore the time value of money (Mandasari et al., 2016).

The formula used to calculate PBP in this study is as follows (Mandasari et al., 2016; Nurmalina \& Riesti, 2010):

$$
P B=\frac{I}{A_{t}} P B=\frac{I}{A_{t}}
$$

I indicate investment cost, and $A_{t}$ is average net benefit every year.

\section{Return of Investment (ROI)}

ROI is a number that shows the ratio between net benefit and invested capital. A positive ROI indicates that the total investment cost can be returned and profit from the remaining investment costs. While negative ROI shows that the income earned cannot cover the total investment costs incurred. Thus, it can be said that a higher ROI will be better than a low ROI. ROI of $100 \%$ means the total investment has been returned. The ROI was formulated follows:

$$
\mathrm{ROI}=\frac{\mathrm{Net} \mathrm{I}_{\mathrm{C}}^{\mathrm{B}}}{\mathrm{I}} \mathrm{ROI}=\frac{\mathrm{Net} \frac{\mathrm{B}}{\mathrm{C}}}{\mathrm{I}}
$$

I is total investment cost.

\section{RESULTS AND DISCUSSION}

\section{Material Characteristic of Product Briquette and It's Air Emission}

Table 1 shows the characteristic of raw material and product briquette in this study. The table shows average value of 17 samples analyzed. We can see that bottoms ash contained high fixed carbon and low volatile matter, whereas biomass contained low fixed carbon and high volatile matter.

The coal waste from textile industry most cannot be used directly and must improve the quality first (Suprapto, 2009) to be able to utilize the caloric value remind (Estiaty et al., 2018; Triantoro et al., 2019). While the biomass 
Table 1. Characteristic Raw Material and Product Briquette

\begin{tabular}{|c|c|c|c|c|c|}
\hline Parameters & Unit & Bottom Ash & Biomass & BCF Product & Coal \\
\hline \multicolumn{6}{|l|}{ Proximate: } \\
\hline Moisture & $\%, a d b$ & 4.36 & 11.74 & 7.39 & 7.90 \\
\hline Ash & $\%, a d b$ & 64.85 & 44.11 & 53.06 & 14.36 \\
\hline Volatile Matter & $\%, a d b$ & 5.12 & 36.61 & 18.29 & 37.05 \\
\hline Fixed Carbon & $\%, \mathrm{adb}$ & 25.67 & 5.14 & 21.26 & 39.20 \\
\hline \multicolumn{6}{|l|}{ Ultimate: } \\
\hline Total Sulfur & $\%, a d b$ & 0.91 & 0.25 & 0.72 & 0.38 \\
\hline Carbon & $\%, \mathrm{adb}$ & 28.01 & 20.83 & 30.97 & 56.47 \\
\hline Hydrogen & $\%, \mathrm{adb}$ & 0.76 & 3.71 & 1.99 & 4.77 \\
\hline Nitrogen & $\%, a d b$ & 0.39 & 0.99 & 0.57 & 1.00 \\
\hline Oxygen & $\%, a d b$ & 5.08 & 27.71 & 15.92 & 21.52 \\
\hline Gross Calorific Value & $\mathrm{cal} / \mathrm{g}, \mathrm{adb}$ & 1952.93 & 1895.53 & 2500.76 & 5341.50 \\
\hline
\end{tabular}

Source: Analysis result (2020)

problems are handling and economic of utilizing. The handling biomass generally was quite tricky because of its low density (Triantoro et al., 2019). Besides low density, the biomass of MSW required handling and processing to be used economically. Based on this fact, this study's aims made both waste materials (bottom ash and MSW as biomass) were more useful, mixed of both materials could be completely burned, and not warm to environment and human health.

Regulation of the Minister of Environment Number 2 of 2008 concerning "Utilization of LB3" in article 7 stated that the utilization of LB3 as a fuel substitution must meet the following criteria, such as 1) calorie content equal to or greater than $2500 \mathrm{kcal} / \mathrm{kg}$ (cal/gram), 2) moisture equal to or less than $15 \%$ and 3 ) not contain halogenated compounds. Based on the study results, as shown in Table 1, the BCF product had fulfilled the first and second criteria. The third criterion was constrained by analysis equipment and become to be our concern for the next study.

This study emphasized to the waste materials utilizing to be valued economic goods by minimizing negative impacts on the environment and human health. This textile industry, where this study conducted is only had limited temporary sites of coal waste disposal. Therefore, they always send coal waste to third parties once every three days. These costs become a burden for the industry during the current economic downturn. The pilot project of bottom ash utilizing could help the company to carry out the disposal problem of coal waste. Then this results of cost-benefit analysis were needed for decision making by the company.

If we only used biomass or bottom ash as a single material, the caloric value was less, whereas moisture content was qualified. Coal bottom ash had a volatile matter, and fixed carbon was 5.12\% (adb) and 36.61\% (adb), whereas biomass had $25.12 \%(\mathrm{adb})$ and $5.14 \%(\mathrm{adb})$. Combining the two compositions material as BCF that causes the heating value was higher than the heating value of its raw material. Volatile matter content in the material served to accelerate the combustion. The utilization of coal bottom ash as fuel is to continue burning coal because the range of volatile matter can not burn the carbon residue (fixed carbon). Bottom ash combined with biomass adds volatile matter content to BCF so that the volatile matter and fixed carbon content are almost equal. Thus it is expected that the carbon residue in the bottom ash will burn out. The total ash combustion of BCF was a safe material for the environment because the ash characteristics were almost the same as soil. The reusing of bottom ash in this study can reduce the pollution environment and simultaneously reducing the use of resources. This was one strategy in clean production (Nugroho et al., 2019) besides clean production in the textile wastewater context (Ozturk et al., 2014).

During the trial burning test (TBT) using the briquette product substitution, we also conducted the air emission monitoring by collaborating with the Center for Textiles and Pulp of Bandung District. 


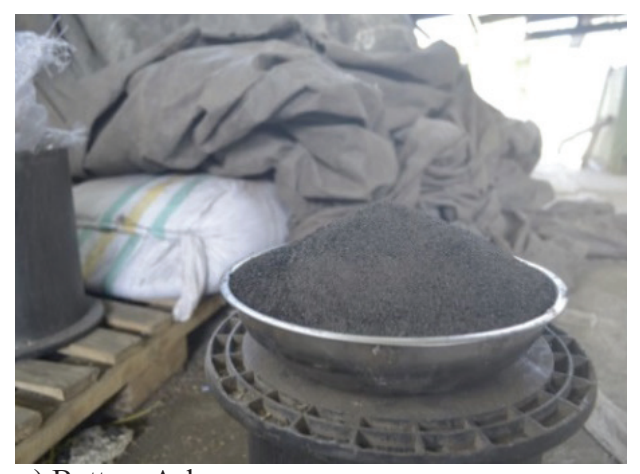

a) Bottom Ash

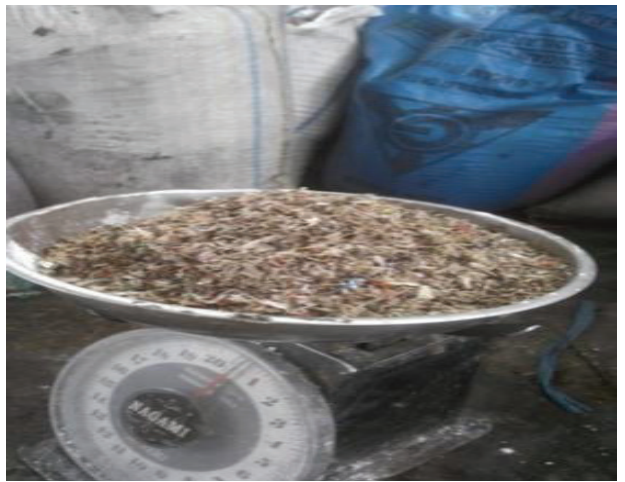

b) Biomass

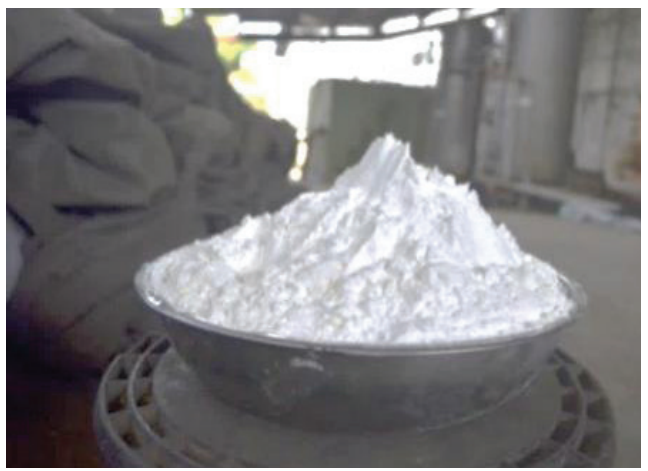

c) Amylum as the binder

Source: Documentation of study (2020)

Figure 1. The raw materials used in this study
Table 2 shows the result of air emission and ambient test from coal combustion with $\mathrm{BCF}$ product substitution. The substitution of $\mathrm{BCF}$ was only conducted in the Omnical boiler, so we compared the emission from its boiler stack with the current emission standard.

During the trial burning test (TBT) using the briquette product substitution, we also conducted the air emission monitoring by collaborating with the Center for Textiles and Pulp of Bandung District. The air emission monitoring was needed to know the impact of BCF substitution on air pollution and boiler performance. Table 2 shows the result of air emission and ambient test from coal combustion with BCF product substitution. The substitution of BCF was only conducted in the Omnical boiler, so we compared the emission from its boiler stack with the current emission standard.

The coal burning emission always contained $\mathrm{CO}_{x}, \mathrm{SO}_{x}, \mathrm{NO}_{\mathrm{x}}$ and particulate. So these parameters become primary parameter to be watched. Based on the air emission monitoring (Table 2 and Table 3), the BCF briquette emissions of coal substitution meet the current emission standard. These data showed that BCF briquette did not given impact significantly to air pollution so it safe for environment. But we can not count the economic assesment of environment impact before and after of BCF substitution due to air pollution impact to human health needs a long data serries. This study was intended only for financial assessment however air emissions of $\mathrm{BCF}$ briquettes as a coal substitution must be ensured it was safe enough for environment.

Table 2. The Results of Air Emission Test with BCF Product Substitution

\begin{tabular}{llllll}
\hline No & Parameter & Unit & $\begin{array}{l}\text { Boiler 1 Stack fueled } \\
\text { coal and BCF }\end{array}$ & Standard* & Method \\
\hline 1 & Particulate**) & $\mathrm{mg} / \mathrm{Nm}^{3}$ & 70.9 & 230 & SNI 7117.12-2005 \\
\hline 2 & Sulfur Dioxide $\left(\mathrm{SO}_{2}\right)$ & $\mathrm{mg} / \mathrm{Nm}^{3}$ & 493.9 & 750 & IK-Paskal.LU.MU-02 \\
\hline 3 & Nitrogen Dioxide $\left(\mathrm{NO}_{2}\right)^{* *}$ & $\mathrm{mg} / \mathrm{Nm}^{3}$ & 370.3 & 825 & IK-Paskal.LU.MU-01 \\
\hline 4 & Opacity & $\%$ & $<20$ & 20 & SNI 7117.11-2005 \\
\hline 5 & Oxygen $\left(\mathrm{O}_{2}\right)$ & $\%$ & 10.8 & - & SNI 19-7117,10-2005 \\
\hline 6 & Flow Rate & $\mathrm{m} / \mathrm{s}$ & 6.5 & - & SNI 7117.12-2005 \\
\hline
\end{tabular}

Source: Analysis result (2020)

Note : *) The standard was based on Government Regulation Number 41 of 1999

**) Measurements were made for 1 hour 
Table 3. The Result of Ambient Air Test

\begin{tabular}{|c|c|c|c|c|c|c|}
\hline \multirow[b]{2}{*}{ No } & \multirow[b]{2}{*}{ Parameter } & \multirow[b]{2}{*}{ Unit } & \multicolumn{2}{|c|}{ The Results of Test } & \multirow[b]{2}{*}{ Standard* } & \multirow[b]{2}{*}{ Method } \\
\hline & & & $\begin{array}{l}\text { Front Area of } \\
\text { Industry** }\end{array}$ & $\begin{array}{l}\text { Behind Area of } \\
\text { Industry** }\end{array}$ & & \\
\hline 1 & TSP (Total Dust) & $\mu \mathrm{g} / \mathrm{Nm}^{3}$ & $<159.9$ & $<159.9$ & 230 & \multirow{7}{*}{$\begin{array}{l}\text { In House } \\
\text { (Sensor } \\
\text { Electro } \\
\text { Chemical) }\end{array}$} \\
\hline 2 & Nitrogen Dioxide $\left(\mathrm{NO}_{2}\right)$ & $\mu \mathrm{g} / \mathrm{Nm}^{3}$ & $<37.6$ & $<37.6$ & 400 & \\
\hline 3 & Sulfur Dioxide $\left(\mathrm{SO}_{2}\right)$ & $\mu \mathrm{g} / \mathrm{Nm}^{3}$ & $<52.2$ & $<52.2$ & 900 & \\
\hline 4 & Carbon Monoxide (CO) & $\mu \mathrm{g} / \mathrm{Nm}^{3}$ & 2248 & 2664 & 30000 & \\
\hline 5 & Ozone $\left(\mathrm{O}_{3}\right)$ & $\mu \mathrm{g} / \mathrm{Nm}^{3}$ & $<39.3$ & 45.83 & 235 & \\
\hline 6 & $\mathrm{NH}_{3}$ & ppm & 0.64 & 0.46 & - & \\
\hline 7 & $\mathrm{H}_{2} \mathrm{~S}$ & $\mathrm{ppm}$ & $<0.01$ & $<0.01$ & - & \\
\hline
\end{tabular}

Source: Analysis result (2020)

Note : *) The standard was based on Government Regulation Number 41 of 1999

**) Measurements were made for 1 hour
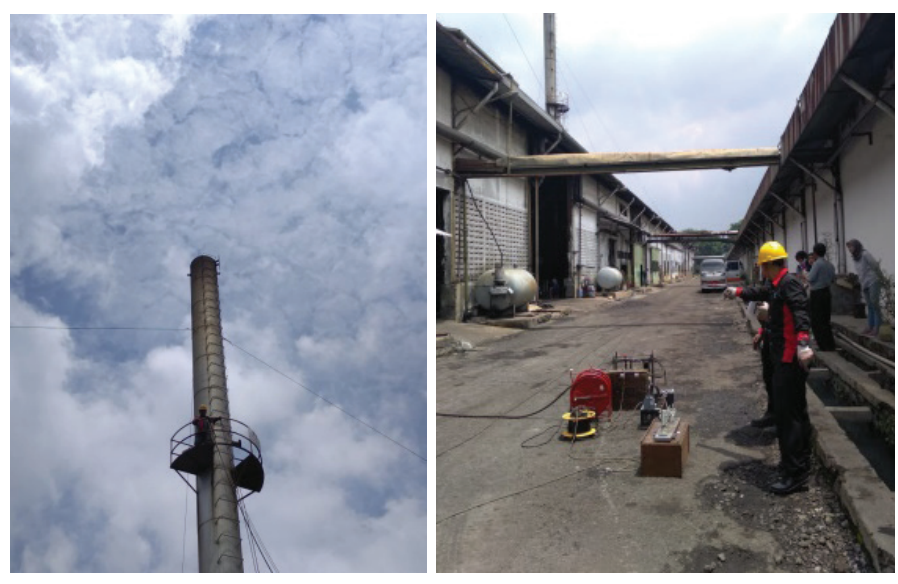

Source: Documentation of Study (2020)

Figure 2. The Air Emission Monitoring

The ash content of fuel contributed to particulate emission (Pasymi, 2008). We can see Table 1, ash content of BCF is more than coal. This will increase the particulate emission. Even though the correlation between the number of biomass adding and particulate emissions increasing was not yet clear. But Table 2 showed that particulate emission of $\mathrm{BCF}$ was lower than emission standard. Morever there was reference stated that biomass can reduce the NOx content of coal combustion (Sutarto et al., 2020). The BCF substitution observation also did not disturb to the Omnical boiler performance. Based on BCF characteristic and its air emission showed that the pilot project was safe enough to technical and environment aspect and potentially to continue.

\section{Cost Estimation}

The capital cost prepared by company consisted of space to work and machines. The briquette making used two equipment, namely mixer machine and briquetting machine. The capacity of each machine is showed on Table 4. These machines become company investment and counted as fixed costs. The purchase of a mixer machine was 30 million rupiahs and a briquette machine was 40 million rupiahs. Other fix cost was the construction space of hangars where briquette production was carried out. The amount of costs incurred by the company for this amounted to 25 million rupiahs. Therefore, the total of fixed costs as company investment was 95 million rupiahs.

Other cost components were cost production as variable costs. Cost production consisted of power consumption, material purchasing used in the production of $\mathrm{BCF}$, gas consumption, and employee salary. This study used the assumption that BCF production was constant every day due to bottom ash limitation availability in this industry. Production was conducted by maximizing of bottom ash availability, which was $150 \mathrm{~kg}$ per day. Table 5 shows the power consumption used during BCF production. The total power of mixer machine was $6 \mathrm{KWh}$ and briquetting machine also $6 \mathrm{KWh}$. So the total power consumption was 12 KWh per day. The current tariff of power used by industry is $\mathrm{Rp} 1,115.00$ per KWh. 
Table 4. Characterization of Machine Usage

\begin{tabular}{lllll}
\hline Equipment Type & Num. of Unit & Operational Time & Capacity & Capacity per-day (kg) \\
\hline Mixer Machine & 1 & 8 & $30 \mathrm{Kg} /$ hours & 240 \\
\hline Briquetting Machine & 1 & 4 & $60 \mathrm{Kg} /$ hours & 240 \\
\hline Source: Analysis result (2020) & & &
\end{tabular}

Source: Analysis result (2020)

Table 5. Power Consumption

\begin{tabular}{llllll}
\hline \multirow{2}{*}{ Equipment } & Power & Number of Unit & Total Power & Usage Timing & $\begin{array}{l}\text { Power } \\
\text { Consumption }\end{array}$ \\
\cline { 2 - 6 } & $\mathbf{( W a t t )}$ & (Unit) & (Watt) & (Jam) & (KWh) \\
\hline Mixer Machine & 750 & 1 & 750 & 8.0 & 6 \\
\hline Briquetting Machine & 1,500 & 1 & 1,500 & 4.0 & 6 \\
\hline Total Power Consumption per day & & 2,250 & & 12 \\
\hline
\end{tabular}

Source: Analysis result (2020)

Table 6. Production Cost

\begin{tabular}{lllllll}
\hline Material & Unit & $\begin{array}{l}\text { Number } \\
\text { Per Day }\end{array}$ & $\begin{array}{l}\text { Unit Price } \\
(\mathbf{R p})\end{array}$ & $\begin{array}{l}\text { Total Price } \\
(\mathbf{R p} / \mathbf{d a y})\end{array}$ & $\begin{array}{l}\text { Total Price } \\
(\mathbf{R p} / \mathbf{m o n t h})\end{array}$ & $\begin{array}{l}\text { Price per Unit } \\
(\mathbf{R p} / \mathbf{K g})\end{array}$ \\
\hline Bottom ash & $\mathrm{kg}$ & 144 & - & - & - & - \\
\hline Biomass & $\mathrm{kg}$ & 96 & 750 & 72,000 & $1,800,000$ & 300 \\
\hline Binder & $\mathrm{kg}$ & 6 & 7,600 & 45,600 & $1,140,000$ & 190 \\
\hline Water & $\mathrm{liter}$ & 64 & 10 & 640 & 16,000 & 3 \\
\hline Gas Consumption & $\mathrm{kg}$ & 0.05 & 147,000 & 7,056 & 176,400 & 29 \\
\hline Salary & person & 2 & 50,000 & 100,000 & $2,500,000$ & 417 \\
\hline Power Consumption & $\mathrm{kwh}$ & 12 & 1,115 & 13,380 & 334,500 & 56 \\
\hline Sum Cost Production & & & & $\mathbf{2 3 8 , 6 7 6}$ & $\mathbf{5 , 9 6 6 , 9 0 0}$ & $\mathbf{9 9 4}$ \\
\hline
\end{tabular}

Source: Analysis result (2020)

Table 7. The Benefit per Month Obtained by Industry

\begin{tabular}{ll}
\hline Items & Benefit (Rp) \\
\hline Benefit from cost of bottom ash disposal & $540,000,-$ \\
\hline Benefit from purchasing of coal substituted & $6,850,000,-$ \\
\hline Sum Benefit per Month & $\mathbf{7 , 3 9 0 , 0 0 0 , -}$ \\
\hline Source: Analysis result (2020)
\end{tabular}

The cost of purchasing material in briquettes production consisted of coal bottom ash, biomass, binder, and water. The other costs for $\mathrm{BCF}$ production were gas consumption and employee salaries. The detail of variable cost in production process can see in Table 6. The total cost of BCF production was Rp 5,966,900 per month or Rp 994 per kilogram unit product.

In addition, investment and cost production, the other costs were maintenance costs for machine and building. A machine maintenance cost was counted as each machine investment to total machines investment multiplied by the machine's depreciation cost. This cost was same every month. At the same time, the building maintenance cost was Rp 40,000 flats every month. So the total maintenance cost was $\mathrm{Rp}$ 625,000 flats every month.

\section{Aggregate of Benefits}

The company achieved the real profits from the disposal costs of coal bottom ash and the purchasing cost of number coal substituted by $\mathrm{BCF}$ briquettes. Table 7 shows the industry benefit gained during $\mathrm{BCF}$ briquettes using as substitution fuel in the industry itself. The company made total benefit of $\operatorname{Rp} 7,390,000$ per month. 
The economic assessment on the utilizing of bottom ash as the bio coal fuel

Table 8. The Calculation of Cost and Benefit of Briquette Product in the Industry (in Rp)

\begin{tabular}{|c|c|c|c|c|c|c|}
\hline Year & $\begin{array}{l}\text { BENEFIT } \\
\text { Accumulation }\end{array}$ & $\begin{array}{l}\text { COST } \\
\text { Accumulation }\end{array}$ & $\begin{array}{l}\text { OM Cost } \\
\text { Accumulation }\end{array}$ & $\begin{array}{l}\text { PV Benefit } \\
\text { Accumulation }\end{array}$ & $\begin{array}{l}\text { PV Cost } \\
\text { Accumulation }\end{array}$ & $\begin{array}{l}\text { Net Return } \\
\text { Accumulation }\end{array}$ \\
\hline 1 & $81,290,000$ & $165,077,500$ & $70,077,500$ & $73,900,000$ & $150,070,455$ & $11,212,500$ \\
\hline 2 & $169,970,000$ & $242,207,500$ & $147,207,500$ & $154,518,182$ & $220,188,636$ & $22,762,500$ \\
\hline 3 & $258,650,000$ & $319,337,500$ & $224,337,500$ & $235,136,364$ & $290,306,818$ & $34,312,500$ \\
\hline 4 & $347,330,000$ & $396,467,500$ & $301,467,500$ & $315,754,545$ & $360,425,000$ & $45,862,500$ \\
\hline 5 & $436,010,000$ & $473,597,500$ & $378,597,500$ & $396,372,727$ & $430,543,182$ & $57,412,500$ \\
\hline 6 & $524,690,000$ & $550,727,500$ & $455,727,500$ & $476,990,909$ & $500,661,364$ & $68,962,500$ \\
\hline 7 & $613,370,000$ & $627,857,500$ & $532,857,500$ & $557,609,091$ & $570,779,545$ & $80,512,500$ \\
\hline 8 & $702,050,000$ & $704,987,500$ & $609,987,500$ & $638,227,273$ & $640,897,727$ & $92,062,500$ \\
\hline 9 & $790,730,000$ & $782,117,500$ & $687,117,500$ & $718,845,455$ & $711,015,909$ & $103,612,500$ \\
\hline 10 & $879,410,000$ & $859,247,500$ & $764,247,500$ & $799,463,636$ & $781,134,091$ & $115,162,500$ \\
\hline 11 & $968,090,000$ & $936,377,500$ & $841,377,500$ & $880,081,818$ & $851,252,273$ & $126,712,500$ \\
\hline 12 & $1,056,770,000$ & $1,013,507,500$ & $918,507,500$ & $960,700,000$ & $921,370,455$ & $138,262,500$ \\
\hline 13 & $1,145,450,000$ & $1,090,637,500$ & $995,637,500$ & $1,041,318,182$ & $991,488,636$ & $149,812,500$ \\
\hline 14 & $1,234,130,000$ & $1,167,767,500$ & $1,072,767,500$ & $1,121,936,364$ & $1,061,606,818$ & $161,362,500$ \\
\hline 15 & $1,322,810,000$ & $1,244,897,500$ & $1,149,897,500$ & $1,202,554,545$ & $1,131,725,000$ & $172,912,500$ \\
\hline 16 & $1,411,490,000$ & $1,322,027,500$ & $1,227,027,500$ & $1,283,172,727$ & $1,201,843,182$ & $184,462,500$ \\
\hline 17 & $1,500,170,000$ & $1,399,157,500$ & $1,304,157,500$ & $1,363,790,909$ & $1,271,961,364$ & $196,012,500$ \\
\hline 18 & $1,588,850,000$ & $1,476,287,500$ & $1,381,287,500$ & $1,444,409,091$ & $1,342,079,545$ & $207,562,500$ \\
\hline 19 & $1,677,530,000$ & $1,553,417,500$ & $1,458,417,500$ & $1,525,027,273$ & $1,412,197,727$ & $219,112,500$ \\
\hline 20 & $1,766,210,000$ & $1,630,547,500$ & $1,535,547,500$ & $1,605,645,455$ & $1,482,315,909$ & $230,662,500$ \\
\hline
\end{tabular}

Source: Analysis result (2020)

Table 9. The Calculation of Benefit Cost Ratio and Payback Period

\begin{tabular}{llll}
\hline Year & Net (B-C) Ratio & Payback Period & ROI \\
\hline 1 & 0.492 & $(1.25)$ & $12 \%$ \\
\hline 2 & 0.702 & $(1.45)$ & $24 \%$ \\
\hline 3 & 0.810 & $(1.72)$ & $36 \%$ \\
\hline 4 & 0.876 & $(2.13)$ & $48 \%$ \\
\hline 5 & 0.921 & $(2.78)$ & $60 \%$ \\
\hline 6 & 0.953 & $(4.01)$ & $73 \%$ \\
\hline 7 & 0.977 & $(7.21)$ & $85 \%$ \\
\hline 8 & 0.996 & $(35.57)$ & $97 \%$ \\
\hline 9 & 1.011 & 12.13 & $109 \%$ \\
\hline 10 & 1.023 & 5.18 & $121 \%$ \\
\hline 11 & 1.034 & 3.30 & $133 \%$ \\
\hline 13 & 1.043 & 2.42 & $146 \%$ \\
\hline 14 & 1.050 & 1.91 & $158 \%$ \\
\hline 15 & 1.057 & 1.57 & $170 \%$ \\
\hline 16 & 1.063 & 1.34 & $182 \%$ \\
\hline 17 & 1.068 & 1.17 & $194 \%$ \\
\hline 18 & 1.072 & 1.03 & $206 \%$ \\
\hline 19 & 1.080 & 0.93 & $218 \%$ \\
\hline 20 & 1.083 & 0.84 & $231 \%$ \\
\hline
\end{tabular}

Source: Analysis result (2020)

\section{Cost-Benefit Calculation}

Table 8 and Table 9 show the calculation of BenefitCost analysis of BCF production. This calculation used the interest rate (r) assumption of $10 \%$. The net benefit/cost ratio was calculated as present value ratio between benefit accumulation and cost accumulation. OM (operational and maintenance) Cost Accumulation is an accumulation cost without investment. Based on the economic assessment, the company got a payback period and net benefit of the project on the ninth year, 
precisely in fourth month of ninth year. In this time, net $\mathrm{B} / \mathrm{C}$ ratio was more than one, and $\mathrm{ROI}$ was $109 \%$ meaningful; the company's investment was 1.09 times. Based on financial calculation, this pilot project had been giving benefits since the first year. It was indicated by the positive net $\mathrm{B} / \mathrm{C}$ ratio; in fact, the profit value cannot return the company's investment for this project on the first year.

The company could achieve more beneficiary if the external (social) cost were included in this calculation. Environmental safety consideration is more important than just looking for profit if the company wants to contribute in a clean industry or clean production strategy. The investments in the waste sector often get impeded because of high costs. This can be helped by issuing rules to facilitate waste even though strict controls need to be carried out by the authorities.

\section{CONCLUSION AND RECOMMENDATION}

The financial calculation and also environmental consideration showed that the pilot project was feasible to continue. The air emission of BCF substitution meet the current standard regulation and the burning test did not disturb the boiler Omnical perform. The net $\mathrm{B} / \mathrm{C}$ ratio of the pilot project was more than one after the ninth years. At that time, the ROI was 1.09 times. The company could buy back some machines that have been invested before the machine's life ends in the tenth year. The company has also achieved positive benefits since the first year namely reducing cost to buy coal and coal waste disposal.

The pilot project was recommended to applied at the others industry which using same boiler and generating the bottom ash. Thus hazardous waste problem of coal ash and burning emission can be reduced. This of course requires policy support from local and national government. The government supporting can make this same project more massive in throughout the coal user industries.

\section{ACKNOWLEDGMENTS}

The authors say thank you to the Finance Ministry of Republic Indonesia who giving funding this study through RISPRO LPDP schema program.

\section{REFERENCES}

Anindhita, F., Sugiyono, A., \& Boedoyo, M. S. (2015). Outlook energi Indonesia 2015: Pengembangan energi untuk mendukung pembangunan berkelanjutan. Jakarta: Pusat Teknologi Pengembangan Sumber Daya Energi, Badan Pengkajian dan Penerapan Teknologi.

Azam, M., Jahromy, S. S., Raza, W., Raza, N., Lee, S. S., Kim, K. H., \& Winter, F. (2020). Status, characterization, and potential utilization of municipal solid waste as renewable energy source: Lahore case study in Pakistan. Environment International, 134(2020), 105291. https:// doi.org/10.1016/j.envint.2019.105291

Babalola, M. A. (2020). A benefit-cost analysis of food and biodegradable waste treatment alternatives: The case of Oita City, Japan. Sustainability (Switzerland), 12(5). https:// doi.org/10.3390/su12051916

Barstow, C., Bluffstone, R., Silon, K., Linden, K., \& Thomas, E. (2019). A cost-benefit analysis of livelihood, environmental and health benefits of a large scale water filter and cookstove distribution in Rwanda. Development Engineering, 4, 100043. https:// doi.org/10.1016/j.deveng.2019.100043

Boardman, A. E., David, H. G., Aidan, R. V, \& David, L. W. (2011). Cost-Benefit Analysis: Concepts and Practice. London: Pearson Ed.

Botfield, J. R., Lacey, S., Fleming, K., McGeechan, K., \& Bateson, D. (2020). Increasing the accessibility of long-acting reversible contraceptives through nurse-led insertions: A cost-benefit analysis. Collegian, 27(1), 109-114. https://doi.org/10.1016/j. colegn.2019.05.001

Brubakken, A. J. (2020). Strategic sourcing of air force contingency pharmaceuticals: a cost-benefit analysis approach. Theses and Dissertations. 3193. https://scholar.afit.edu/ etd/3193

Chadburn, O., Anderson, C., Venton, C. C., \& Selby, S. (2013). Applying cost benefit analysis at a community level. Oxford: Oxfam Research Reports June 2013. http:// policy-practice.oxfam.org.uk/publications/ 
applying-cost-benefit-analysis-at-acommunity-level-a-review-of-its-use-forcom-303558

de Ruig, L. T., Haer, T., de Moel, H., Botzen, W. J. W., \& Aerts, J. C. J. H. (2020). A microscale cost-benefit analysis of building-level flood risk adaptation measures in Los Angeles. Water Resources and Economics, 32(June), 100147. https://doi.org/10.1016/j. wre.2019.100147

Elpawati, E., Nugraha, A. T., \& Shofiatina, R. (2018). Kelayakan usaha ayam broiler (studi pada usaha peternakan di Desa Cibinong). Caraka Tani: Journal of Sustainable Agriculture, 33(2), 96-105. https://doi. org/10.20961/carakatani.v33i2.19090

Estiaty, L. M., Fatimah, D., \& Sutjijo. (2013). Material ringan berpori berbahan dasar abu terbang. Conference Proceeding Pusat Penelitian Geoteknologi-LIPI.

Estiaty, L. M., Fatimah, D., \& Widodo. (2018). Bio-coal briquettes using low-grade coal. IOP Conference Series: Earth and Environmental Science, 118(1). https://doi. org/10.1088/1755-1315/118/1/012066

Haryadi, H., \& Suciyanti, M. (2018). Analisis perkiraan kebutuhan batubara untuk industri domestik tahun 2020-2035 dalam mendukung kebijakan domestic market obligation dan kebijakan energi nasional. Jurnal Teknologi Mineral dan Batubara, 14(1), 59-73. https://doi.org/10.30556/jtmb. vol14.no1.2018.192

Imaduddin, M., Hermawan, H., Hadiyanto, H., \& Wawan, W. (2014). Pemanfaatan sampah sayur pasar dalam produksi listrik melalui microbial fuel cells (Utilization of market vegetable waste in electricity production through microbial fuel cells). Media Elektrika, 7(2), 22-35.

Isamu, I., Salam, I., \& Yunus, L. (2018). Analisis kelayakan usaha budidaya udang vaname pola tradisional plus di Kecamatan Samaturu Kabupaten Kolaka. Jurnal Sosio Agribisnis. 3(1), 41-48. http://dx.doi.org/10.33772/jsa. v3i1.7400

James, A. K., Thring, R. W., Helle, S., \& Ghuman, H. S. (2012). Ash management review-applications of biomass bottom ash. Energies, 5(10), 3856-3873. https://doi. org/10.3390/en5103856

Jayaranjan, M. L. D., van Hullebusch, E. D., \& Annachhatre, A. P. (2014). Reuse options for coal fired power plant bottom ash and fly ash. Reviews in Environmental Science and Biotechnology, 13(4), 467-486. https://doi. org/10.1007/s11157-014-9336-4

Johnson, J. (2014). U4 issue (10th ed., Issue 10). CMI-Chr. Michelsen Institute.

Jugović, A., Slišković, M., \& Vukić, L. (2018). Concept of external costs calculation in the ports: Environmental impacts. Tehnicki Vjesnik, 25, 495-502. https://doi. org/10.17559/TV-20161201113235

Kamble, A. D., Saxena, V. K., Chavan, P. D., \& Mendhe, V. A. (2019). Co-gasification of coal and biomass an emerging clean energy technology: Status and prospects of development in Indian context. International Journal of Mining Science and Technology, 29(2), 171-186. https://doi.org/10.1016/j. ijmst.2018.03.011

Karo-karo, P., \& Sembiring, S. (2008). Karakteristik abu hasil pembakaran batubara bukit asam sebagai bahan keramik. Ilmu Dasar, 9(2), 127-134.

Kurniadi, D. S., Syarief, R., \& Suryani, A. (2017). Strategi pengembangan usaha produk tekstil di PT Priangan Sentosa Tasikmalaya, Jawa Barat. MANAJEMEN IKM: Jurnal Manajemen Pengembangan Industri Kecil Menengah, 12(1), 63-74. https://doi.org/10.29244/mikm.12.1.63-74

Makul, N. (2020). Cost-benefit analysis of the production of ready-mixed high-performance concrete made with recycled concrete aggregate: A case study in Thailand. Heliyon, 6(6), e04135. https://doi.org/10.1016/j. heliyon.2020.e04135

Malico, I., Pereira, R. N., Gonçalves, A. C., \& Sousa, A. M. O. (2019). Current status and future perspectives for energy production from solid biomass in the European industry. Renewable and Sustainable Energy Reviews, 112(November 2018), 960-977. https://doi. org/10.1016/j.rser.2019.06.022 
Mandasari, M., Yusmini, \& Tety, E. (2016). Analyze feasibility financial proper by using dump of cow waste to produce biogas (Study case: livestock Pondok Pesantren Khairul Ummah, Air Molek, Indragiri Hulu). Jom Faperta. 3(2): 1-11. https://jom.unri. ac.id/index.php/JOMFAPERTA/article/ view/14697/14246

Mardansyah, J. (2008). Dampak penggunaan briket batubara dibandingkan dengan bahan bakar lain terhadap keluhan pernafasan kronik pekerja di UKM. Kesmas: National Public Health Journal, 2(4), 173-178. https://doi.org/10.21109/kesmas.v2i4.261

Marganingrum, D., Estiaty, L. M., Irawan, C., \& Hidawati. (2020). The biomass coal fermented (BCF) briquette as an alternative fuel. MSCEIS 2019 Conference Proceeding, 1, 811-819. https://doi.org/10.4108/eai.1210-2019.2296375

Masters, R., Anwar, E., Collins, B., Cookson, R., $\&$ Capewell, S. (2017). Return on investment of public health interventions: A systematic review. Journal of Epidemiology and Community Health, 71(8), 827-834. https:// doi.org/10.1136/jech-2016-208141

Nugroho, G. S. F., Sulistyaningrum, R., Melania, R. P., \& Handayani, W. (2019). Environmental analysis of tofu production in the context of cleaner production: case study of tofu household industries in Salatiga, Indonesia. Journal of Environmental Science and Sustainable Development, 2(2), 127-138. https://doi.org/https://doi.org/10.7454/jessd. v2i2.1021

Nurmalina, R., \& Riesti, S. (2010). Analisis biaya manfaat pengusahaan sapi perah dan pemanfaatan limbah untuk menghasilkan biogas pada kondisi risiko (Studi kasus: Kecamatan Cisarua dan Megamendung, Kabupetan Bogor, Jawa Barat). Jurnal Pertanian, 1(1), 17-34.

Ozturk, E., Karaboyaci, M., Koseoglu, H., Yigit, N. O., Yetis, U., \& Kitis, M. (2014). Water and chemical management studies for cleaner production in a textile industry. Chemical Engineering Transactions, 39, 493-498. https://doi.org/10.3303/CET1439083
Palupi, M., Fitriadi, R., Prakosa, D. G., \& Pramono, T. B. (2020). Analisis kelayakan usaha pembenihan ikan kerapu cantang (Epinephelus sp.) di Desa Blitok, Situbondo. Samakia : Jurnal Ilmu Perikanan, 11(2), 101-107. https://doi.org/10.35316/jsapi. v11i2.830

Pasaribu, K. F., \& Sukandar. (2017). Analisis manfaat biaya pengelolaan limbah spent bleaching earth melalui pemanfaatan dan penimbunan dengan memperhitungkan nilai gas rumah kaca. Jurnal Tehnik Lingkungan, 23(2), 33-42. https://doi.org/10.5614/j. t1.2017.23.2.4

Pasymi. (2008). Batu bara (Jilid 1). Padang: Bung Hatta University Press.

Prasandha, A. F. E., Triwulan, \& Ekaputri, J. J. (2015). Paving geopolimer berbahan dasar. Jurnal Teknik ITS, 4(2), 2-7.

Pratiwi, H., Nurmalina, R., \& Rifin, A. (2020). Studi kelayakan pendirian kantor cabang baru PT. XYZ di Provinsi Kalimantan Timur. Jurnal Studi Manajemen Dan Bisnis, 7(2), 103-113. https://doi.org/10.21107/jsmb. v7i2.9047

Santoso, I., \& Roy, S. K. (2003). Pengaruh penggunaan bottom ash terhadap karakteristik campuran aspal beton. Civil Engineering Dimension, 5(2), 75-81. http:// puslit2.petra.ac.id/ejournal/index.php/civ/ article/view/15572

Setiawan, B., Lahjie, A. M., Yusuf, S., \& Ruslim, Y. (2019). Assessing the feasibility of forest plantation of native species: A case study of Agathis dammara and Eusideroxylon zwageri in Balikpapan, East Kalimantan, Indonesia. Biodiversitas Journal of Biological Diversity, 20(9), 2453-2461. https://doi.org/10.13057/biodiv/ d200904

Sidhu, A. S., Pollitt, M. G., \& Anaya, K. L. (2018). A social cost benefit analysis of grid-scale electrical energy storage projects: A case study. Applied Energy, 212(January), 881-894. https://doi.org/10.1016/j. apenergy.2017.12.085

Slamet, S., \& Gunawan, B. (2016). Bio briket campuran bottom ash batu bara limbah PLTU 
dan biomassa melalui proses karbonasi sebagai sumber energi terbarukan. Prosiding SNATIF Ke-6 Tahun 2019, 43-50.

Sososutiksno, C., \& Gasperz, J. (2017). Economic and financial feasibility of abalone culture development in Hulaliu village, District of Maluku Tengah, Maluku Province. AACL Bioflux, 10(6), 1492-1498.

Špačková, O., \& Straub, D. (2015). Cost-Benefit analysis for optimization of risk protection under budget constraints. Risk Analysis, 35(5), 941-959. https://doi.org/10.1111/ risa. 12310

Sulistyowati, N. A. (2013). Bata beton berlubang dari abu batubara (fly ash dan bottom ash) yang ramah lingkungan. Jurnal Teknik Sipil Dan Perencanaan, 15(1), 87-96. https://doi. org/10.15294/jtsp.v15i1.7117

Suprapto, S. (2009). Penanganan limbah pembakaran batubara pada pabrik tekstil: studi kasus pabrik tekstil di Kabupaten Bandung. Jurnal Teknologi Mineral Dan Batubara, 5(2), 19-31. https://jurnal. tekmira.esdm.go.id/index.php/minerba/ article/view/904

Sutarto, H., Nurrohim, T. G., Ilyas, A. X., \& Suyitno, S. (2020). Pembakaran bersama biomassa dan batu bara: Pengaruh rasio biomassa-batu bara dan excess air. Mekanika: Majalah Ilmiah Mekanika, 19(1), 29-34. https://doi.org/10.20961/mekanika. v19i1.40039

Syafrudin, S., Zaman, B., Indriyani, I., Erga, A. S., \& Natalia, H. B. (2015). The utilization of bottom ash coal for briquette products by adding teak leaves charcoal, coconut shell charcoal, and rice husk charcoal. Waste Technology, 3(1), 14-21. https://doi. org/10.12777/wastech.3.1.14-21

Triantoro, A., Mustofa, A., Kartini, K., \& Hanafi, A. (2019). Studi analisa kualitas biobriket campuran bottom ash batubara dan onggok tepung tapioka menggunakan karbonisasi. Jurnal Fisika FLUX, 1(1), 54-60. https:// doi.org/10.20527/flux.v1i1.6147

Turner, R. K., Pearce, D., \& Bateman, I. (1994). Environmental economics, an elementary introduction (first publ). Harvester Wheatsheaf.

Wang, L., Watanabe, T., \& Xu, Z. (2015). Monetization of external costs using lifecycle analysis-A comparative case study of coal-fired and biomass power plants in Northeast China. Energies, 8(2), 1440-1467. https://doi.org/10.3390/en8021440

Wild, A. J., Wilson, T. M., Bebbington, M. S., Cole, J. W., \& Craig, H. M. (2019). Probabilistic volcanic impact assessment and cost-benefit analysis on network infrastructure for secondary evacuation of farm livestock: A case study from the dairy industry, Taranaki, New Zealand. Journal of Volcanology and Geothermal Research, 387, 106670. https://doi.org/10.1016/j. jvolgeores.2019.106670

Yudiartono, Anindhita, Sugiyono, A., Wahid, L. M. A., \& Adiarso. (2018). Outlook energi Indonesia 2018: Energi berkelanjutan untuk transportasi darat. Angewandte Chemie International Edition, 6(11), 951-952. Pusat Pengkajian Industri Proses dan Energi (PPIPE), Badan Pengkajian dan Penerapan Teknologi. https://d1 io3yog0oux5.cloudfront.net/ d7a71c03e5d9d1d6e246eb7c02ef1111/ continentalenergy/db/337/2200/pdf/BPPT + Outlook+Energi+Indonesia+2018

Yunita, E. (2017). Pembakaran batubara pada pembangkit listrik tenaga uap (PLTU) PT. Semen Tonasa (Bachelor Thesis). UIN Alauddin, Makassar, Indonesia. http:// repositori.uin-alauddin.ac.id/8427/

Yusuf, M. (2012). Studi pengaruh waktu perendaman abu batubara PLTU sebagai bahan penyerap logam berat lindi smapah perkotaan (Disertasi). Universitas Sriwijaya, Palembang, Indonesia. https://repository. unsri.ac.id/25254/

Zultaqawa, Z., Alexandri, M. B., Rizal, M., Kostini, N., \& Aulia, M. D. (2019). Pengaruh aksesibilitas, IT dan aksi kompetitif pada usaha mikro kecil dan menengah. Responsive, 2(1), 25-32. https://doi.org/10.24198/ responsive.v2i1.23020 